\title{
Anvar obidjon is a children's poet
}

\author{
Nigora Adizova Bakhtiyorovna \\ Doctor of Philosophy (PhD) in Philology \\ Teacher of Bukhara State University \\ Nodira Adizova Bakhtiyorovna \\ Doctoral student of \\ Bukhara State University
}

\begin{abstract}
This article focuses on A. Obidjon, who played a special role in the development of children's poetry and prose. At the same time, the artist, who thinks about the development of Uzbek children's drama, has created a dramatic epic, a play. Anvar Obidjan is an artist who has enriched not only children's prose and poetry, but also dramaturgy, as a children's poet, known as a prose writer, he won the admiration of his fans with his dramatic works.
\end{abstract}

Key words: talent, creativity, poetry, poet, education, upbringing, punster, verse, finger weight, rhyme, medicine, reader, wonderful, plant, fruit, vegetable, artistic image tools, trickery, art.

\section{I.Introduction}

Anvar Obidjan, a talented and beloved children's poet, began his career by writing poetry. So far, he has been entertaining children by writing beautiful poems with a rich philosophy, playful tone and unique rhyme. Poetry not only educates but also educates students.

I am a cheerful joy

Pistachio

I am a master of

Witticism!

[Quvnoq shodon

Pistaman

Askiyaga

Ustaman!]

The poet likens the pistachio to an askiyachi because of its open mouth, and the reader animates the pistachio in front of his eyes. At the same time, it educates the student in two ways:

I smiled

And smiled.

Who likes it

Glum?

[Jilmayganim

Jilmaygan.

Kimga yoqar

Tumtaygan?] 


\section{II.Literature review}

The student understands that it is good to be open-minded and bad to be blunt.

Why don't you

Caress me

Why don't you bite me

One by one.

Do you like it?

Your mind

So

You have a toothache. (Page 10)

[Nega meni

Erkalab

Chaqmayapsiz

Bittalab.

Yoqmi sira

Hushingiz

Demak

Chatoq tishingiz].

First of all, there is a lack of poetry. The poem is written in four- and three-syllable finger weights. But in the last two verses this situation is broken. One line consists of two syllables and one line consists of five syllables.

The poem is rhymed in the form of $\mathrm{a}-\mathrm{b}-\mathrm{v}-\mathrm{b}-\mathrm{g}-\mathrm{b}$, ie only a couple of lines. The poem has only four and three syllables, so there is no place for it. The original poem was composed of seven verses, rhyming in the form of a masnavi, and its stanzas were $3+4$. But the poet used such a form, considering that it is convenient for children of kindergarten and small school age.

\section{III.Analysis}

The reader says that pistachios should be chewed with a toothpick, and for a person with unhealthy teeth, pistachio bites are a problem. The poem is light, playful, and educational. That is why there are so many readers of such poems.

Let's meet,

I am apricot.

I am

Plum partner. (11-p).

[Tanishaylik,

O'rikman.

G'aynoliga

Sherikman].

The reader of Anvar Obidjan's poems should be knowledgeable. At the same time, if the student does not have enough knowledge, it is necessary to explain the knowledge to him, that is, let the children read the poems of Anvar Obidjan, memorize them and try to explain their content. Teachers in difficult situations need help. Because after reading the above lines, the reader has a question: why partner with apricot kernels? To do this, the reader must know that apricots are synonymous with apricots. The Uzbek people know a number of types of plums. Olu, oluda, alipolu, girdolu, apricot ... so yellow plum is apricot. The student who knows that the apricot is involved in the harvest will enjoy, and the student who does not know will learn. It seems that the four lines of the poem are both instructive and educative: 
I am for now rice.

Don't complain

From my hair (23-p).

[Men hozircha

Sholiman.

Qipig'imdan

Nolima].

The little one listens to the poem with pleasure and memorizes it quickly. Learn what rice is. Learn how to make rice from rice. At the moment, there is a slight sense of humor in the poem.

My skin hurts

Peel

In objuvoz

Crushed.

[Po'stim tushar

Archilib

Objuvozda

Yanchilib].

Objuvoz for a child is an unfamiliar word, the reader searches for the word "objuvoz", gets new information, the vocabulary is enriched with another word. The poet continues to teach:

Don't stop now

Itchy head

Cook quickly

Milk soup. (P. 23)

[Endi turma

Qashib bosh

Tezda pishirvor

Sut osh].

Through the poet's light laughter, a child appears in front of the poet with his head bowed. He starts thinking about what milk soup is. He learns that milk soup is shirgurunch. "Shir" is a Tajik word, so the Uzbek name of the dish is milk soup. Anvar Obidjan's poems mention fruits, vegetables and melons, and the poet gives interesting information about them. While the reader enjoys the poet's wonderful knowledge of biology and medicine, he enjoys the tone of the poem and the rhyming rhymes.

Anvar Obidjan pays special attention to the collection of poems. Let's take a look at the "Very Interesting Story" collection. Usually the first poem in the collection is the introduction to the book. Anvar Obidjan also quotes the poem "Khabar Seller" and says that his poems in the book are rich in novelty and he wants children to read them with interest:

I sell new words,

Old sayings, too.

Stay tuned guys

Very little left. (Page 3)

[Yangi gaplar sotaman,

Eski gaplar ham.

Bolajonlar kep qoling,

Qoldi juda kam].

The poem is not an exhortation or a dry word; it is natural for children to find it interesting because of the images and scenes: 
Let the sun shine on the tiger

Walking around,

It fainted in the mirror

Seeing the opposite. (3-p)

[Quyosh yo'lbars terisin

Yopinib yurib,

Hushdan ketdi ko'zguga

O'z aksin ko'rib].

The book is also important because it is organized on specific topics. The first part is called "From the fields to the children." The title is followed by a photo and a line that explains the nature of the section:

The farmer called the old man his grandfather,

I bow and say hello. (P. 5)

[Dehqon cholni bobom deb,

Egilaman salom deb].

\section{IV.Discussion}

The poet first published poems about plants such as wheat, cotton, then vegetables, fruits, and so on, the disadvantage of which is that vegetables, fruits, and melons are not placed in order, but added and mixed. For example, first "Vegetables", then "Watermelon", "Grapes", "Turnip", "Fig", "Garlic Onion", "Pistachio", "Handalak", "Apricot". rs are placed in series. However, they could be arranged in the order of plants, fruits, vegetables and melons. The second part of the book is called The Wonderland and is summarized as follows:

The dog barked from the porch:

-Hello from all animals (Page 25).

[It ulidi ayvondan:

-Salom hamma hayvondan].

Apparently, the characters in this part of the book are animals. But the flaw in the first part seems to have been repeated, that the poems are arranged in a chaotic manner.

The goat says:

-Oh, doctor,

I wish you had children.

I have a sore throat

Stuck Ant. (P. 27)

[Echki der:

-O, do'xtirjon,

Bo'l uvali-juvali.

Panjasini ko'zimga

Tiqib oldi Chumoli].

These lines in the poem will not offend you. But other content is understood using the title. Notice the following verses from the Excuse Hospital:

The beetle is crippled

Click on the dog's foot.

The mouse is stretched

The mule's ear. (Page 27)

[Qo'ng'iz mayib qilganmish

Bosib itning oyog'in.

Sichqon esa cho'zganmish 
Xachirvoyning qulog'in].

The poems are inspiring, informing the reader about animals, birds, their behavior, and their individual aspects. The poem "Aunt Chittak" makes the reader think:

She had woken a basket house

Chittakvoy's aunt.

He asked what it was

From him the elephant's son.

He replied with a smirk

Old, irritable Chittak,

Interference in the work of adults,

Tomboy! (Page 30)

[To'qir edi savat uy

Chittakvoyning xolasi.

Bu nima deb so'radi

Undan filning bolasi.

Javob qildi tumshayib

Qari, jahli tez Chittak,

-Kattalarning ishiga

Aralashma,

Tirmizak!]

The poem seems to depict a natural phenomenon vividly. But the poet is skilled. He described the incident in such a way that you are hesitant to draw conclusions. Each reader draws his own conclusions. that is the magnitude of the poet. Is the baby elephant taller than the old chittagong? Even if the old man is silent, is he older than the baby elephant because of his life experience ?! That's why he has the right to say "tirmizak" ?! The poet's purpose is hidden. The movie is hidden. You feel helpless, you think a lot.

Anvar Obidjan encourages the younger generation to know nature, to use it properly, to understand why we call it mother nature. Each of his poems educates, educates, educates.

Anvar Obidjan is not only a talented poet, but also a talented poet. He is a writer who has made a worthy contribution to Uzbek children's prose. It has been many years since his prose works such as "O bright world ...", "Stories of Bahrom", "Terrible Meshpolvon", "Battles of Meshpolvon", "Alamazon and his infantry" found a reader and became famous. . The writer's prose is dominated by the desire for independence and longing for freedom. For example, Meshpolvon's struggle against Sepkilshah began only in the hope of rescuing his parents, but gradually expanded in the struggle for the country, for the people, for freedom, and gained social status.

From the beginning to the end of the 20th century, the Soviet government and the Russian nationalists at its head tried to deprive our Motherland of its rights. The younger generation was taught that "the Uzbek people are backward, and the Soviet government brought them happiness, literacy, and technical progress." These lies put the creators of the 70's and 80's on their feet. Anvar Obidjan can also express his heartache through the fate of such heroes as Meshpolvon and Alamazon. The writer was able to show that we were traitors because of the traitors inside us. In "Meshpolvonningjanglari" there is Mutal - a drunkard. He sells his countrymen and wants to get rich that way. He deceived his countrymen into believing that he would be their own master and submitted them to Sepkilshah. Mutal - the drunkard lives in a mirage, that is, he is forced to live as if there is nothing. This can be seen in the episode in which he pretends to believe in this lie, as if he were setting the table for the guests and eating.

The author describes a city that voluntarily surrendered to Sepkilshah: That's probably it. " Anvar Obidjan believes that those who quietly submit to the enemy will be defeated. It is well known that our great artists used the image of a beggar to exaggerate a tragedy. Gado is the image of a wise man who knows the 
transience of the world, who has no possessions, and who knows the spoils of this day. Remember Hazrat Navoi's gado, which amazed Alexander. Continuing the tradition of creative work, the teacher introduces the image of gado in the story of Anvar Obidjan. Gado gives the following painful conclusion: "There are three kinds of demons in the world: a king who feeds the people with plunder, an official who approves of what the king says, and a citizen who joins these two demons." That's the decent thing to do, and it should end there. It was a short, symbolic expression of the tragedy of the $80 \mathrm{~s}$. It is no coincidence that the author's story was not considered "a leaflet distributed to the children of a dependent state."

\section{V.Conclusion}

Anvar Obidjan's prose is unique not only in its ideas but also in its art. She is good at using art tools. The author's prose works use portraits, landscapes, allusions, rhetoric, and folklore. Let's take a look at the following passage from the story "O bright world ..." it was known only to those who lived here.

When a writer uses landscape in his prose, he evokes the image of the place, delights the reader, reveals the mood of the protagonist, and enhances the impact of the events. Anvar Obidjan enhances the art of his works by making effective use of not only landscapes, but also dozens of art tools. "The squirrel raised his eyebrows exactly four feet and stroked his cat's mustache, which looked like a cat's, and looked at Alamazon." In this passage, the epithet "eyebrow eyebrow", the four widths of the eyebrows, the equality of the mustache with the cat's tail, created the art of exaggeration and allegory. A mustache has always been a form of resemblance, a means of resemblance. At the same time, the writer likens Tirtik's mustache to a cat's tail, creating a negative mood in the reader towards the protagonist. That's the decent thing to do, and it should end there. After all, Anvar Obidjan's works do their best to be interesting and artistically mature.

Poet and prose writer A. Obidjon is a talented artist who constantly writes poems, epics, fairy tales and short stories for children. That is why reading, propagating and researching fairy tales is one of the most important tasks of our time. According to the scientist, the fairy-tale-story, the fairy-tale-novel, the fairy-taleprose type, the fairy-tale-lyro-epic type, the fairy-drama-drama type.

\section{References:}

1. Anvar Obidjon. Very interesting story. T: Yulduzcha, 1987, 10-p.

2. Anvar Obidjon. Alamazon and Gulmat. T: Spirituality, 1998, p.

3. Anvar Obidjon. O bright world ... p.

4. Adizova N. "The role of ethnotoponym in the toponym of bukhara District" International Scientific Journal Theoretical \& Applied Science p-ISSN: 2308-4944 (print) e-ISSN: 2409-0085 (online) Year: 2020 Issue: 01 Volume: 81 Published: 30.01 .2020 http://T-Science.org 414-416

5. Adizova N. Nominal description of the bukhara district. International Journal of Recent Technology and Engineering (IJRTE) ISSN:2277-3878 Volume-, Issue-3S, October 2019.

6. Adizova N. The Main Motives and Objectives of fun genre in folklore. International Journal of Innovative Technology and Exploring Engineering (IJITEE) ISSN: 2277-3878, Volume-8, Issue-3S, October 2019. -Pp.202-207.

7. Adizova N. Rhyme, rhythm in fun genre. International Scientific Journal Theoretical \&Applied Science p-ISSN:2308-4944(print) e-ISSN: 2409-0085(online) Published: 09.10.2019. -Pp. 65-67.

8. Adizova N, Adizova N The role of the fun genre in children's spiritual development. Middle european scientific bulletin ISSN 2694-9970 Published: 09.09.2020. -Pp.38-40

9. Adizova N, Adizova N The role of oikonyms in microtoponymis of Bukhara district . Middle european scientific bulletin ISSN 2694-9970. 09.09.2020.-Pp.41-43 
10. Akhmedova, M. B. (2019) "ANALYSIS OF -SPIRITUALITY\| CATEGORY AND ITS STRUCTURE IN THE ENGLISH LANGUAGE," Central Asian Problems of Modern Science and Education: Vol. 4 : Iss. 2 , Article 136.

11. M.B. Ahmedova. Genetic and Structural Specifications of tge Spirituality Nominative Units in the Uzbek Language. -Theoretical and Applied Science, 10 issue. 2018.- p.331-333

12. Nilufar Ulmasovna Ochilova, Mehrinigor Bahodirovna Ahmedova. Reflections on Horse in Uzbek Prose.- Theoretical and Applied Science, 10 issue, 2019. - p. 86-88. 